\title{
UTILIZING CLASSROOM ACTION RESEARCH IN INDONESIAN TERTIARY STUDENTS' ENGLISH SPEAKING CLASS
}

\author{
Imelda Gozali \\ Universitas Katolik Widya Mandala Surabaya \\ Imelda.gozali@ukwms.ac.id
}

\begin{abstract}
Proficiency in productive skills, most notably speaking, has been commonly regarded as a gauge of success in learning English. It is common to find many non-English department colleges include English speaking classes, apart from general, grammar-based lessons, in the list of their general basic subject. The purpose of this research is to improve the spontaneous English speech of students in an Indonesian tertiary institute in such English conversation class. The study was carried out using Classroom Action Research methodology, with 80 students as the subjects. The 'plan' stage comprised the exercise of Error Analysis methodology, based on the data of erroneous English speech of the students. The Corrective Feedback constituted the 'act' stage, wherein the writer deliberately gave different types of Corrective Feedback during and/or after the students' spontaneous speech. In the 'observe' and 'result' stage, the writer concluded that teaching Basic Phonics, which is usually taught to children when learning to read, might be necessary to improve students' pronunciation. Students were also receptive to $\mathrm{CF}$ from the teacher and could retain some feedback given by their peers. Based on the outcome of this study, it is suggested that Basic Phonics be included as part of English Conversation or English Speaking curriculum, even at tertiary level. At the same time, English teachers should not hesitate to provide Corrective Feedback to improve the speech of their students, as well as to encourage peer feedback to be given by friends.
\end{abstract}

Keywords: Classroom Action Research, Corrective Feedback, English Speaking Error Analysis, English for Indonesian Tertiary Students

\section{INTRODUCTION}

Communicating effectively in English has been identified as one of the key factors of successful implementation of ASEAN Economic Community (AEC) actions and programs (Widiati and Hayati, 2015). As such, apart from the usual Grammar-focused English subjects given at tertiary level, some non-English department colleges include English Communication skills in their curriculum, with greater emphasis on listening and speaking. Despite the best effort of the instructors and the students, it is evident that students still make mistakes when speaking English, be them in the area of grammar, vocabulary or word choice, as well a pronunciation. While some of these mistakes are still comprehensible by fellow Indonesians, they might hamper understanding to native or near-native English speakers in the context outside Indonesia (Gozali, 2018). Thus, there is a need to analyze the most frequently committed errors in the English speech of 
tertiary students, and to find the best way to remedy the problem. The most classical approach to analyze errors would be the Error Analysis method, which traditionally has been utilized by practitioners and researchers to classify the different types of errors and to find their source (Al Khresheh, 2016). Some studies have also shown the usefulness of Corrective Feedback in order to address those errors (Sheen and Elis, 2011).

As far as the topic of Error Analysis on English speech of Indonesian students is concerned, few studies analyzed grammatical errors of spontaneous speech of English students (Sastra, 2014; Sondiana, 2017), and only one study was found that dealt with pronunciation (Sudrajat, 2016). On the other hand, several studies on students writing errors are available (Gayo and Widodo, 2018; Hapsari, 2012; Napitupulu, 2017; Wahyudi, 2012). For Corrective Feedback (CF), there was a study by Khunaivi and Hartono (2015) on the use of CF by English teachers in a secondary school in Indonesia. Thus, investigating the errors in Indonesian tertiary students' speech from all aspects (syntactic, lexical, and pronunciation), as well as finding out the ways to correct those particular errors, is still necessary and relevant.

The writer has been teaching English for several years in a tertiary institute, whose directors place great emphasis on the English communication skill of all graduates. Therefore, besides making English an MKDU or Mata Kuliah Dasar Umum (General Basic Subject) taken mandatorily by students of all courses, the college makes it compulsory for all students to also take the English Conversation Class (ECC), which consists of four levels with emphasis on communication skill. For this subject, students need to sit for a placement test, after which they will be assigned to the four levels based on their scores. Hence, even the most proficient student will have to take at least a semester of the ECC classes. The lessons in ECC are geared towards productive skills namely speaking, listening, and conversational competence.

In the course of listening to the students' speech during the ECC classes, the writer came across errors and mistakes committed by the students, which perhaps can be considered typical of Indonesian learners. While some errors are minor, and the overall meaning can still be comprehended, others either invite unintentional laughter or inhibit comprehension altogether. Therefore, bearing in mind the demands of AEC 2015 and the vision of the school's directors as described above, it is essential that a study is done to look into those errors and address them accordingly. It was then decided to analyze the speaking errors of the students through Error Analysis, and to carry out Corrective Feedback to remedy those specific errors.

Besides mapping out the errors in speaking as stated above, the writer is also interested to improve her own teaching method in this communicative class. As such, it was felt that the most appropriate methodology for this research is Classroom Action Research (CAR). CAR is deemed to be more practical and able to bring direct consequences on the specific issues that the teacher-researcher desire to investigate (Burns, 2009). Studies done with CAR methodology is typically carried out in cycles, with each cycle consisting of planning, action, observation. This study was planned to consist of two cycles, with the result of the first cycle being fed into the second. 
In summary, the writer intends to improve the spontaneous English speech of her students through Classroom Action Research. Specifically, she is interested to find out in her ECC class: (1) the type of errors committed by the students through simple Error Analysis, (2) the effectiveness of the different types of Corrective Feedback, (3) the perception and uptake of such corrections by the students.

\section{LITERATURE REVIEW}

\section{Error Analysis}

Error Analysis is the process of identifying the incorrect utterances or writings of the language learners, collecting and classifying them, as well as attempting to discover the cause of such errors (Al-Khresheh, 2016). A famous study done by Richards in 1970 on Error Analysis outlined two types of errors, namely interlanguage and intralingual or developmental errors, committed by English language learners. Interlanguage errors are those which might arise due to interference from the learners' mother tongue. On the other hand, intralingual or developmental errors are attributed to the inherent difficulties within the language being learned, and thus can be committed by any language learners regardless of their native tongue. Examples of errors in the second group are did he comed, what you are doing, he coming from Israel, make him to do it, etc. (Richards, 1970).

The causes of intralingual/developmental errors vary from overgeneralization to hypothesizing false concepts. Errors are, contrary to popular belief, valuable for teachers, students, and researchers alike. Errors help teachers to assess the learning achievement of the students, help students to test their assumptions on the language learned, and are valuable resources for researchers in the field of Second Language Acquisition (Corder, 1967). Al-Khresheh (2016) similarly described the steps taken in Error Analysis, namely collection of error samples, identification of errors, description of errors, and lastly explanation of errors (Ellis, 1994). In the case of Indonesia, Sastra (2014) had conducted a study on errors committed by Indonesian tertiary students while speaking, focusing on the errors in grammatical aspect.

Al-Khresheh (2016) pointed out the pedagogical benefits of Error Analysis for teachers. It helps them, according to him, to understand the difficulties experienced by learners due to First Language interference, literal translation, cross-cultural influence, etc. For example, teachers can emphasize instances in the linguistic aspect being taught where a literal translation is not applicable.

\section{Corrective Feedback}

Corrective Feedback ("CF”) can be broadly classified as of 'recast' type, wherein the correct form is supplied by the teacher in a subtle manner, repeating what the students said and replacing the erroneous part with the correct form. The other type is termed 'prompts', in which the teachers elicit the correct form from the learners. Sheen and Elis (2011) provided a more comprehensive classification of oral $\mathrm{CF}$, segregating them into implicit (geared towards communication) and explicit (intended for didactic purpose), as well as those meant to provide input (explicit correction and recast) and output (clarification request, elicitation, metalinguistic clue, and repetition). 
In terms of language acquisition theories, $\mathrm{CF}$ receives its support from both the interaction hypothesis in the case of recast, since it brings the learners' attention to the gap between their errors and the correct forms, as well as from the skill acquisition theory for prompt, because it provides the necessary practice for the students in a meaningful discourse (Lyster, Saito, Sato, 2013). It was found that recast is more suitable for correcting errors for newly-acquired language form (Lyster, 2002), whereas prompt is fitting for language forms that learners are already familiar with (Lyster, 2004). The use of CF is also dependent on several variables such as linguistic aspect being addressed; prompt, especially negotiation of forms, is preferred for errors in grammar and lexicon (Lyster, 1998). When it comes to the learners' proficiency, Hampl (2011) found that several studies showed that it is more advisable to use prompt, rather than recast, for language learners with lower proficiency.

The use of oral CF in communicative tasks seem to be a common practice across different instructional setting and linguistic focus, as shown by a metalinguistic study examining the effectiveness of CF in 15 classroom studies in North America, Europe and Asia (Lyster and Saito, 2010). CF was performed in a variety of communicative tasks, such as role play, jigsaw tasks, and group discussion (Sheen, 2004). Regarding the choice of CF in classroom conversations, teachers generally prefer to give recast since, when administered appropriately, it doesn't disrupt the flow of thoughts of the students and avoids causing embarrassment to them (Yoshida, 2010). The effectiveness of CF in classroom settings has been thoroughly documented and reviewed by Lyster et. al. (2013). A hypothesis has even been put forward on the need to balance communicative activities with explicit teaching and CF (Lyster and Mori, 2006).

Since CF is generally supplied by the teachers, and to a certain extent by peers, it is essential to know both the perception of the learners themselves in receiving the feedback, as well as the effectiveness, from their perspective, of such error treatment. Some research discovered that students had a somewhat negative perception of error correction (Loewen et al., 2009), while others found out that they viewed it as beneficial (Schulz, 2001).

Nevertheless, metalinguistic studies on $\mathrm{CF}$ in recent times showed a clearer tendency towards the preference of students to receive oral CF rather than to have their errors passed unchecked, and even have it done immediately after their illutterances (Lyster, Saito and Sato, 2013). This tendency is more marked in students in an EFL environment, i.e., not immersed in the target language (Lyster, Saito and Sato, 2013). Students also seem to simply expect the teachers to do all the corrections, and this might be due to the teachers' own belief as to their responsibilities to provide a comprehensive correction, at times to the detriment of the students (Lee, 2013). Examining the cultural background of the Target Language and that of the students, some research revealed that students studying Arabic and Chinese were more appreciative of corrective feedback (Loewen et. al, 2009). The explanation proffered was that perhaps those two languages were markedly different from the native language of the students. Yang and colleagues (2006), who studied the perception of Chinese EFL (English as Foreign Language) students to peer and teacher Corrective Feedback, found that the students' preference to teachers' correction might be due to the Confucian culture, which confers greater respect to the authority (Yang, Badger \& Yu, 2006). 


\section{Classroom Action Research}

Classroom Action Research (CAR) is seen as the middle ground between simply reflective teaching, which might seem subjective and lack academic rigor, and pure scientific research which could be seen as wanting in practicality and relevance to the actual classroom scenario (Farrell, 2007). Usually, the teacher is also the researcher who conducts the CAR in his/her own classroom. This classroom research is typically done in a cycle, which starts with identifying the supposed phenomena in the classroom that needs changing, planning the improvements to be carried out, effecting the planned actions, observing and collecting the data the supposed changes that happen as a result of the planned actions, and lastly, reflecting on the data collected.

Data collection is usually done through field notes, journal writing, or interviewing a focused group. The result of the reflection is then fed into the planning of the next cycle. The most famous CAR model is perhaps that proposed by Kemmis and McTaggart (1988), which consists of Plan, Act, Observe and Reflect. Thus, in this systematic manner, the teacher-researcher can obtain valuable data that support his/her intuition on the supposed 'problem' in the classroom, and provide specific remedy to address it.

Farrell (2006) made use of CAR to find out about Singapore teachers' belief in grammar correction and the actual practice in their writing class. They found out that the teachers believed that all grammatical errors in the students' writing have to be corrected, and they actually do so in class. However, after reading some literature on the effectiveness of correcting only specific errors, they were convinced and slowly changed their teaching practice. In Indonesia, a CAR with three cycles aimed of improving students' speaking skill was carried out with success by Afrizal (2015). In his study, Information Gap Technique was used to overcome the reluctance of the students to speak English. His analysis revealed that, with every cycle, the mean score of the test result improved.

\section{METHOD}

\section{Participants and Period}

The participants in this study were 80 students from five intact ECC classes. The students came from various non-English departments such as engineering and design, and from mixed level of study as well since their ECC classes are determined by a placement test. They had to take the ECC classes as a kind of mandatory, English enrichment class. In this study, the students were at ECC level 2 , which is equivalent to a score of less than 465 in TOEFL.

The period of the study was one semester, or the equivalence of fourteen (14) weeks of face-to-face class meetings. Each meeting is typically initiated with a lecture and exercises on grammar which is related to the conversation topic being discussed. This lasts around 30 minutes, and is then followed by the speaking session lasting 60 minutes, which can be individual or in groups, where the students talk or present about the indicated topic.

\section{Procedures and Data Analysis}

Classroom Action Research (CAR) was chosen as the methodology of the research, since the main thrust of this study is to improve the students' speaking skill, as well as to reflect on the writer's own teaching practice and method. For 
this study, two cycles were carried out; the first cycle lasted for seven weeks before the mid-term examination (February 6 - March 24, 2017), and the second cycle the subsequent seven (April 10 - May 26, 2017). The first cycle of the Planning phase constitutes the preparation for the instruments to be used in the subsequent Observation phase, namely the making the Pre-Class Questionnaires and Observation Sheet. The Pre-Class Questionnaires was designed to find out the perception of students to error correction, to get a feel of their take on this matter. The Questionnaires were given in Bahasa Indonesia, the native language, so as to minimize errors arising from incomprehension or misunderstanding. The Observation Sheet would be used by the writer to list down the errors that the students made in the course of their speaking tasks. It contains columns to indicate the erroneous words or sentences, and the division into errors in pronunciation, grammar, and vocabulary.

The Action phase of Cycle One was initiated by distributing the Pre-Class Questionnaires to all the students during the first day of class. A quick analysis of the results of this questionnaire revealed that the students generally have positive perception of oral corrections by teachers and peers, which was a positive indication for this study to proceed further. In the ensuing six weeks, the usual ECC lessons were carried out in accordance with the school's syllabus. However, the writer also took down the samples of erroneous speeches in the Observation Sheet while the students present their speaking tasks individually or in the group. Thus, those six weeks constituted the Observation Phase and the data collection process of Cycle One.

In the Reflection phase, the data gathered from the Pre-Class Questionnaires and the Observation Sheet were analyzed for aspects that could contribute to the Cycle Two process or to the research as a whole. The errors observed in the Observation Sheet which were more frequently-committed or the ones that might hinder or obstruct comprehension to native speakers ("Selected Errors") were sifted out and compiled. The questionnaires results were charted using Microsoft Excel® and studied, to see if there were things to be further observed, done, or omitted in Cycle Two.

In Cycle Two, it was decided during the Planning Phase that some items of the Selected Errors compiled in Cycle One above were to be explicitly taught to the students ("Highlighted Errors"), and thus constituted a form of Explicit Correction and part of Corrective Feedback. It was hoped that it would help the students to realize the mistakes, remember, and self-correct in future speech. Not all items in the Selected Errors could be explained to the students due to time constraint. Thus, during the Action Phase of Cycle Two, the Highlighted Errors were explained in the first lesson after the mid-term break.

The subsequent, remaining six lessons constituted the Observation Phase of Cycle Two, wherein the writer observed once again if students still committed the Highlighted Errors or other errors, while at the same time provided Corrective Feedback to the students when deemed appropriate. The results of this observation were noted in the Observation Sheet. Finally, in the last class of the semester, the writer distributed the Post-Class Questionnaires so as to get the students' perception of the Corrective Feedback given, as well as to elicit once again the attitudes and perception towards correction, after 14 weeks of the lessons. The Reflection Phase of Cycle Two thus consisted in compiling and studying the data 
obtained from the Observation Sheet, as well as the Post-Class Questionnaire results, again using Microsoft Excel ${ }^{\circledR}$ as the tool to display the results.

\section{FINDINGS}

The list of more frequently-committed speaking errors in the chosen three linguistic area ("Selected Errors") that were noted during the Observation Phase of Cycle One is shown in Figure 1 below.

\begin{tabular}{|c|c|c|c|c|}
\hline & \multicolumn{2}{|c|}{ Pronunciation } & Grammar & Lexicon \\
\hline 1 & $\begin{array}{l}\text { ansWer, } \\
\text { Who }\end{array}$ & bUses & $\begin{array}{l}\text { can speaking, can flying, } \\
\text { can feeling, ... }\end{array}$ & I very like \\
\hline 2 & stUdy & boxES & $\begin{array}{l}\text { I going/back home, I } \\
\text { chatting }\end{array}$ & $\begin{array}{l}\text { I school in } \\
\text { SMA, he school } \\
\text { at ... }\end{array}$ \\
\hline 3 & campUs & $\begin{array}{l}\text { concernED, } \\
\text { banNED }\end{array}$ & $\begin{array}{l}\text { watching a TV, drink a } \\
\text { coffee, have a lunch, ... }\end{array}$ & $\begin{array}{l}\text { When I success, } \\
\ldots\end{array}$ \\
\hline 4 & $\begin{array}{l}\text { brOWsing, } \\
\text { shOWer, } \\
\text { crOWded }\end{array}$ & $\begin{array}{l}\text { tUrn, } \\
\text { chUrch }\end{array}$ & can lookS like & broom the floor \\
\hline 5 & hOUse & invITE & You must to come & \\
\hline 6 & batterY & finGer & $\begin{array}{l}\text { how to writing, to drawing, } \\
\text {... }\end{array}$ & \\
\hline 7 & sCene & cenTRE & $\begin{array}{l}\text { he do(es), he (does) not } \\
\text { want to, people doesn't }\end{array}$ & \\
\hline 8 & Know & fuTURE & he climbing & \\
\hline 9 & stUdent & mountAIn & will promoting & \\
\hline 10 & magazINE & wOrk & $\begin{array}{l}\text { I doesn't know, you } \\
\text { doesn't need }\end{array}$ & \\
\hline 11 & $\begin{array}{l}\text { Hours, } \\
\text { Honest }\end{array}$ & bUIld & My school have a ... & \\
\hline 12 & oppoSITE & $\begin{array}{l}\text { SundAY, } \\
\text { pAY }\end{array}$ & It make(s) you & \\
\hline 13 & eVENT & sUGGest & $\begin{array}{l}\text { was need(ed), was go } \\
\text { (went) }\end{array}$ & \\
\hline 14 & & VIOlent & $\begin{array}{l}\text { she is fall(s) in love, is } \\
\text { begin }\end{array}$ & \\
\hline
\end{tabular}




\begin{tabular}{|l|l|l|l|}
\hline 15 & & that (is) located & \\
\hline 16 & & Do you ever confused... & \\
\hline 17 & & $\begin{array}{l}\text { more easy, more better, } \\
\text { more faster }\end{array}$ & \\
\hline
\end{tabular}

Figure 1: Selected Errors and Highlighted Errors

As has been described above, some of the Selected Errors in the table above were taken up to be explained to the students in the first lesson of Cycle Two ("Highlighted Errors"). The words or structure which made up the Highlighted Errors are shown shaded in the box in Figure 1.

For the Corrective Feedback, the writer attempted to apply some corrections in all the lessons both in Cycle One and Cycle Two of the research period. Among the different types of feedback available, the writer found that she could mainly use the Recast and Explicit Correction types. This is because most of these corrections happened during students' individual presentation, in which the writer did not wish to disrupt the students' flow of words and train of thoughts. Thus, only when the errors occurred frequently within the same speech, the writer then interrupted the students' speech by providing Recast. Otherwise, the writer would wait till the end of the students' speech to provide an Explicit Correction. In some of the instances of the Recast, the writer noted that some of the students were unaware of the correction, while others would acknowledge the correction with immediate repair. For one low-proficiency student, it was noted that he was given a Recast type of correction once on his pronunciation of the word 'student', but, although he acknowledged it, the repair didn't take place.

Finally, the results of the Post-Class Questionnaire are shown here in Figure $2 \mathrm{~A}$ and $2 \mathrm{~B}$. As has been mentioned above, this questionnaire was drafted in order to find out if the students could recall any of the corrections, as well as to get their general perception about correction once again.

Figure 2A

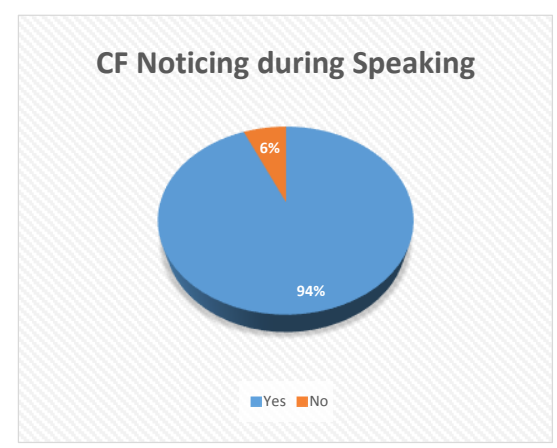

Figure 2B

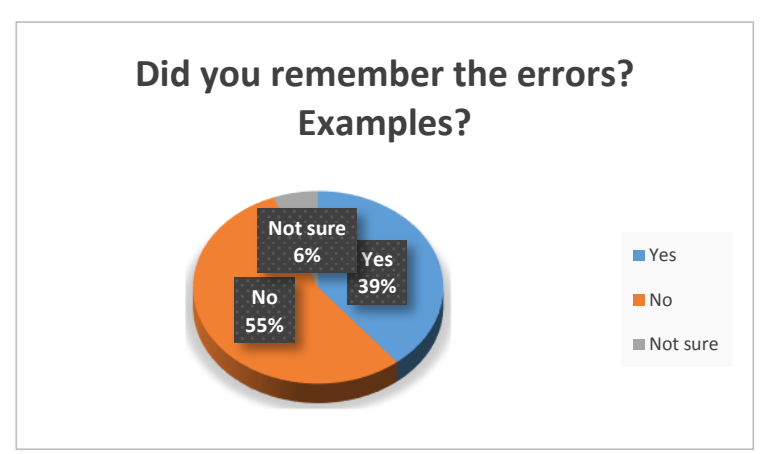

Figure 2: Post-Class Questionnaire

The results in Figure 2A revealed that an overwhelming majority (94\%) recalled that they were corrected in their speech during the previous ECC classes. However, when they were asked to mention if they remember the specific language items being corrected, Figure 2B showed that there were more students saying that they don't remember $(55 \%)$ or unsure $(4 \%)$, and only $39 \%$ wrote that they remembered. Some of the open-ended answers given by the latter group 
about the linguistic aspect corrected were some grammar, such as the past tense, the -ing form, modals (would, will, could, should), and others related to pronunciation. A student mentioned one of the words in the Highlighted Errors, namely the pronunciation of the word "study".

The last question of the questionnaire is a series of dichotomous questions meant to elicit the students' responses, whether they agree or disagree, to statements relating to their preferences on corrections and potentials of learning derived from corrections. The questions are extracted from, with slight adaptation, similar questionnaires done by Schulz (2001) when she set out to study the perception of English as a Foreign Language (EFL) students at a postsecondary level in Colombia on the role of error correction in learning English. The English translation of the six questions are tabulated below, and the corresponding results presented as a graph in Figure 3.

1. I dislike it when I am corrected when speaking English in class.

2. Teachers should not correct students' speaking errors in class unless these errors interfere with comprehensibility.

3. When I make errors in speaking this language, the teacher should correct them.

4. I prefer to be corrected by my fellow students in small group rather than by my teacher in front of the entire class.

5. I can learn when my teacher corrects the errors made by my fellow students in class.

6. I can learn when my teacher corrects the errors I make in class.

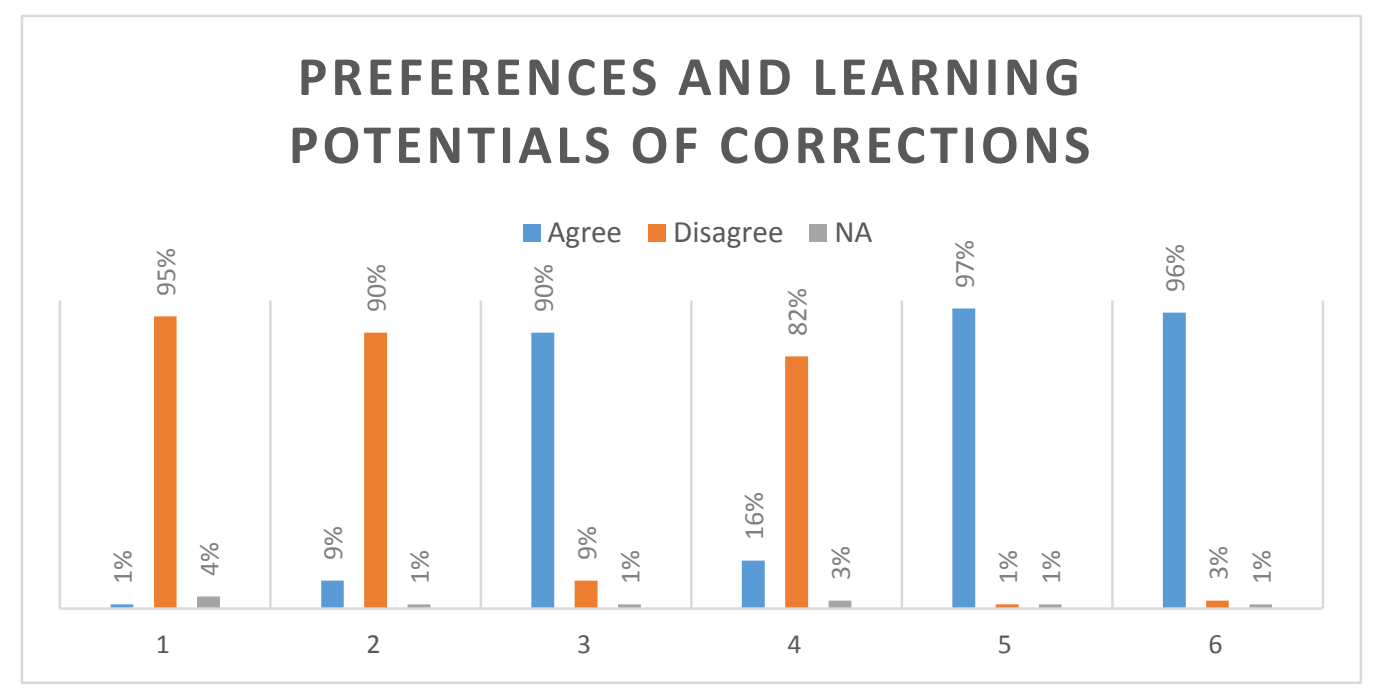

Figure 3: Preferences and Learning Potentials of Corrections.

\section{DISCUSSION}

As regards the first research question, namely to find out the types of errors committed by the students, it can be seen that most of the grammatical errors, like "can speak*ing*" and "must *to* come", can be classified to be intralingual and they look like the list of errors termed by Richards (1970, Appendix) as intralingual-developmental errors. Sample speeches like "can look*s* like" is similar to his example of the case of generalization, while "*was go*" comes from 
hypothesis of false concept, in which the form "was" is interpreted by the speaker as time marker of past tense.

Wijaya (2012) also observed similar errors, such as the ones in "drink *a* coffee" or "have *a* lunch", and termed it overusing of articles. When it comes to errors in pronunciation, it was also revealed that most of them are intralingual as well. It can generally be said that, since some phonetic forms in English do not exist in Indonesian, such as silent $\mathrm{W}$, silent $\mathrm{K}$, the $\mathrm{OW}$ and the OU sounds, the students then attempted to pronounce them in a way that is similar to Bahasa Indonesia. Only in some instances of word pronunciation, specifically those actually derived from English, did the influence of L1 was quite apparent and so gave rise to interlingual errors. For example, the word studi and baterai exist in Bahasa Indonesia, so negative transfer happened in those occasions. The lexical errors are evidently L1 interference, whereby the speakers translated literally from L1 to English. For example, in the phrase "I *broom* the floor", the speaker might think translated the Indonesian verb menyapu, from the root word sapu (broom), into that erroneous phrase instead of using the verb "sweep".

All of these results, although deficient in Error Analysis properly speaking, have pedagogical values for the writer. Besides providing material for Explicit Correction as has been stated above, the writer is now more convinced of the need to impart some basic Phonics material to the students in order to pre-empt phonetic errors like silent letters and diphthongs above. Phonics is a basic literacy subject given to pre- and primary school children where English is used as the first language. Since Phonics is not taught to children in English as Foreign Language (EFL) context, it might be useful to adapt some Phonics lessons to suit the need of Indonesian students. The list of errors is also useful as insights on things to be highlighted or emphasized when teaching those aspects in the future. It is hoped that the success of Saito (2011), who gave explicit phonetic instruction to the students as well as Recast, can be replicated in future research.

When it comes to finding the effectiveness of various types of Corrective Feedback in answer to the second purpose of this study, the writer only managed to provide Recast and Explicit Correction thus only those two could be evaluated. Inferring from the results of the Post-Class Questionnaire, it can be conjectured perhaps that Recast and Explicit Correction were effective in the sense that the students remembered being corrected (Figure 2A), but not the specific items being corrected (Figure 2B). Another implication is that this study then corroborated the results of Hampl (2011) stated above, that recast may not be as effective as prompt for less proficient language learners. The fact that the $\mathrm{CF}$ was not given in a context of meaningful interaction (Spada and Lightbown, 1993), and only as a feedback to a monologue, is another possible cause of the ineffectiveness of the $\mathrm{CF}$ observed in this research. Besides, the anxiety triggered by speaking in front of the class might have hindered the corrective effectiveness of the $\mathrm{CF}$ in the mind of the students, who will then not benefit from them (Sheen, 2008)

Finally, as to the quest of finding the perception and uptake of students of such corrections as contemplated by the third purpose of this work, this research result joins a host of other research outcomes regarding students' positive preference and perception of Corrective Feedback (Lyster, Saito, Sato, 2013), although this research perhaps has contributed somewhat in that nothing much has been written about oral corrective feedback in Indonesia. The writer also shared 
the conclusion of Schulz (2001), who surmised that the preference for CF in the case of Columbian students studying English, as compared to students of other backgrounds studying English in the US in her study, might be due to the emphasis placed on Grammar for the Columbian students, as contrasted with fluency for the students in the US. As cross-cultural note, it was observed in some of the answers to the open-ended question that, although corrections are welcomed, students wished them be given in a polite, friendly manner. This is perhaps part of an Asian concept of the fear of 'losing face', especially in public.

Comparing the results of questions posed by Schulz (2001) which were adopted and adapted by the writer, similar pattern emerged, except for question no. 4 , which deals with preference for peer-correction. Figure 4 below shows the comparison between the two questionnaires' outcomes.
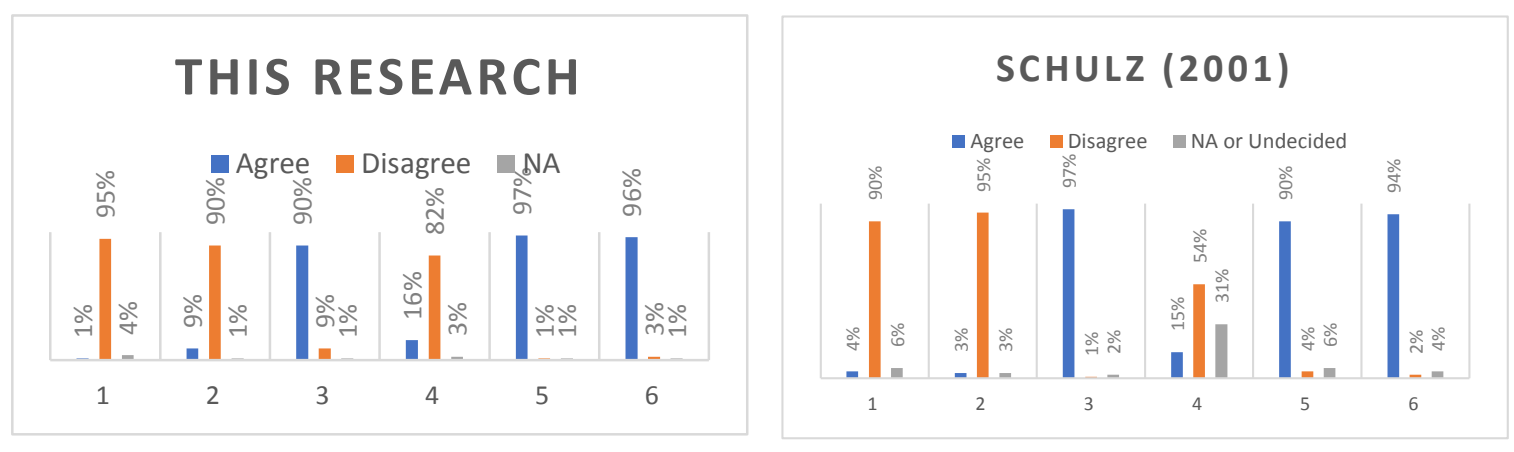

Figure 4: Comparison between the result of this Research and that of Schulz (2001)

As can be seen for question no. 4, more students in this research disagree with peer correction (82\%) than the students in Schulz' study (54\%). Hence, on the surface, it appears that Indonesian students still prefer to be corrected by their teachers instead of by peers. In this regard, Foster and Ohta (2005) termed peercorrection as 'face-threatening'; their studies indicated that students preferred to encourage each other in order to elicit self-repair, as compared to negotiating meaning in a conversation. However, when done with deliberation, such as training the students to give feedback to one another, the outcome might be more constructive (Sato and Ballinger, 2012).

\section{CONCLUSION}

There is hardly any study done in Indonesia on doing Corrective Feedback on spontaneous speech in English, based on specific errors which are frequently committed by Indonesian tertiary students. This study then set out to analyze and classify the errors made in the spontaneous English speech of Indonesian tertiary school students through Error Analysis, to try addressing those mistakes using Corrective Feedback and to find out the usefulness of the corrective method, with Classroom Action Research as the research methodology. The simple Error Analysis done to samples of erroneous utterances by the students in this study showed that they committed many phonological errors, some grammatical or morpho-syntactic errors, and a few lexical ones. Most of them were intralingual in nature, with few instances of L1 interference's case. 
This has pedagogical values for ESL teachers of Indonesian origin, or those teaching in Indonesia, specifically to see areas which need more emphasis in the classroom. It is proposed that Basic Phonics, which is usually given to children where English is the native language, can be taught to adult learners in Indonesia to address the phonological errors. In the case of Corrective Feedback, Recast and Explicit Correction did provide some benefits to the students since they at least remembered being corrected, although most couldn't remember the specific corrected items. For $\mathrm{CF}$ to be effective, teachers should procure a way to provide the prompt type of feedback. Lastly, teachers should not hesitate to provide CF to students since they are positively perceived in general.

\section{REFERENCES}

Afrizal, M. (2015). A classroom action research: Improving speaking skills through information gap activities. English Education Journal, 6(3), 342355.

Al-Khresheh, M. H. (2016). A review study of error analysis theory. International Journal of Humanities and Social Science Research, 2, 49-59.

Burns, A. (2009). Doing action research in English language teaching: A guide for practitioners. Routledge.

Corder, S. P. (1967). The significance of learner's errors. IRAL-International Review of Applied Linguistics in Language Teaching, 5(1-4), 161-170.

Ellis, R. (1994). The study of second language acquisition. Oxford University.

Farrell, T. S. (2006). Reflective practice in action: A case study of a writing teacher's reflections on practice. TESL Canada Journal, 77-90.

Farrel, T. S. (2007). Action research. Reflective Language Teaching: From Research to Practice, 94-106.

Foster, P., \& Ohta, A. S. (2005). Negotiation for meaning and peer assistance in second language classrooms. Applied linguistics, 26(3), 402-430.

Gayo, H., \& Widodo, P. (2018). An Analysis of Morphological and Syntactical Errors on the English Writing of Junior High School Indonesian Students. International Journal of Learning, Teaching and Educational Research, 17(4), 58-70.

Gozali, I. (2018). Local vs global errors: comprehensibility judgment on the speech of Indonesian students by native speakers. Language in the Online \& Offline World 6: The Fortitude, 152

Hampl, M. 2011. Error and error correction in classroom conversation: a comparative study of CLIL and traditional lessons in Austria. Vienna: University of Vienna.

Kemmis, S. M., \& Taggart, M. R.(Eds.).(1988). The action research planner.

Khunaivi, H., \& Hartono, R. (2015). Teacher's and student's perceptions of corrective feedback in teaching speaking. English Education Journal, 5(2).

Lee, E. J. E. (2013). Corrective feedback preferences and learner repair among advanced ESL students. System, 41(2), 217-230. 
Loewen, S., Li, S., Fei, F., Thompson, A., Nakatsukasa, K., Ahn, S., \& Chen, X. (2009). Second language learners' beliefs about grammar instruction and error correction. The Modern Language Journal, 93(1), 91-104.

Lyster, R. 1998. Negotiation of form, recasts, and explicit correction in relation to error types and learner repair in immersion classrooms. Language learning,48(2), 183-218.

Lyster, R. 2002. Negotiation in Immersion Teacher-Student Interaction. International Journal of Educational Research, 237-253.

Lyster, R. 2004. Differential Effects of Prompts and Recasts in Form-Focused Instruction. Studies on Second Language Acquisition, 399-432.

Lyster, R., \& Mori, H. (2006). Interactional feedback and instructional counterbalance. Studies in second language acquisition, 28(2), 269-300.

Lyster, R., \& Saito, K. (2010). Oral feedback in classroom SLA: A meta-analysis. Studies in second language acquisition, 32(2), 265-302.

Lyster, R., Saito, K., \& Sato, M. (2013). Oral corrective feedback in second language classrooms. Language teaching, 46(1), 1-40.

Napitupulu, S. (2017). Analyzing linguistic errors in writing an English letter: A case study of Indonesian undergraduate students. International Journal of Language and Linguistics, 5(3), 71-77.

Richards, J. C. (1970). A Non-Contrastive Approach to Error Analysis.

Saito, K. (2011). Examining the role of explicit phonetic instruction in native-like and comprehensible pronunciation development: An instructed SLA approach to L2 phonology. Language awareness, 20(1), 45-59.

Sastra, L. V. (2014). Grammatical error analysis on the spontaneous speech produced by students of English. Jurnal Ilmiah Mahasiswa FIB, 3(8).

Sato, M., \& Ballinger, S. (2012). Raising language awareness in peer interaction: a cross-context, cross-methodology examination. Language Awareness, 21(1-2), 157-179.

Schulz, R. A. (2001). Cultural differences in student and teacher perceptions concerning the role of grammar instruction and corrective feedback: USA- Colombia. The Modern Language Journal, 85(2), 244-258.

Sheen, Y. (2004). Corrective feedback and learner uptake in communicative classrooms across instructional settings. Language teaching research, 8(3), 263-300.

Sheen, Y. (2008). Recasts, language anxiety, modified output, and L2 learning. Language Learning, 58(4), 835-874.

Sheen, Y., \& Ellis, R. (2011). Corrective feedback in language teaching. Handbook of research in second language teaching and learning, 2, 593610.

Sondiana, S. D. (2017). An analysis of grammatical errors in speech at the students of English Education Study Program of Muhammadiyah Unyiversit of Metro academic year 2013/2014. Premise: Journal of English Education, $3(2)$. 
Spada, N., \& Lightbown, P. M. 1993. Instruction and the development of questions in L2 classrooms. Studies in Second Language Acquisition, 15(02), 205-224.

Sudrajat, A. (2016). An Analysis of English Pronunciation Based On Student Speech Community At English Education Study Program. English Education Program. Teacher Training And Education Faculty. University Of Lampung.

Widiati, U., \& Hayati, N. (2015). Teacher professional education in Indonesia and ASEAN 2015: Lessons learned from English language teacher education programs. Stroupe, R., \& Kimura, K.(Eds.), ASEAN integration and the role of English language teaching, 121-148.

Wijaya, D. (2012). Teaching English generic nouns: The exploration of the generic idea in English and Indonesian and the applications of explicit instruction in classroom. Indonesian JELT, 8(1), 93-107.

Yang, M., Badger, R., \& Yu, Z. (2006). A comparative study of peer and teacher feedback in a Chinese EFL writing class. Journal of second language writing, 15(3), 179-200.Yoshida, R. (2008). Teachers' choice and learners' preference of corrective feedback types. Language awareness, 17(1), 78-93 